Mandzyuk I.A.,

Prysiazhna K.O.

Khmelnytskyi National University,

Khmelnytskyi, Ukraine

E-mail: Ekaterina1601@i.ua

\section{INVESTIGATION OF THE INFLUENCE OF THICKENERS AND FILLERS ON PROPERTIES OF LUBRICANTS OBTAINED BY RECYCLING TECHNOLOGIES}

UDC 685.34042

DOI: $10.31891 / 2079-1372-2019-91-1-52-58$

The possibility of obtaining a new class of the bases of lubricants by modifying the natural fat molecule by a fragment of a link of synthetic polymer - polyethylene terephthalate is considered. The influence of thickeners of various chemical nature is considered: paraffin P400, beeswax, aerosil 200, modified bentonite, sodium stearate and lithium stearate on antifriction characteristics of PET-acylglycerol based on beef fat. The influence of fillers, namely: aerosil 200, modified with quaternary ammonium salts bentonite clay (particle size is $20 \mathrm{~nm}$ ), talc, graphite and molybdenum disulphide on the value of static shear stress and anti-wear properties are considered.

Key words: natural fat, PET-acylglycerol, IR spectrogram, grease, tribotechnical properties, friction coefficient.

\title{
Introduction
}

The term "green" means a new round of scientific thinking, which includes views on the ecological balance and principles of environmental protection. The industry of lubricants in the perspective of new thinking "green tribology" provides among many tasks: - ecological aspects of manufacturing new lubricants with the use of renewable raw materials and their biodegradation after the end of their life cycle. Potential raw materials for the creation of environmentally friendly lubricants are vegetable oils, animal fats and synthetic alcohol esters $[1,2]$.

For lubricants, from the point of view of material science, it is important to solve two problems:

- to ensure the production of natural, renewable raw materials;

- to create lubricants with high tribotechnical properties and capable of independent biodegradation after the end of the cycle of operation.

In developing the technology of chemical recycling of waste polyethylene terephthalate (PET bottles) by glycerolysis, Professor Mandzyuk I.A proposed a mechanism of the process with the formation of oligomeric products - recyclables of different molecular weights [3]. The process of chemical recycling of PET, in the framework of the presented model, was considered as consisting of a sequence of reactions: the destruction of the main chain of polyethylene terephthalate under the action of degradation agent - glycerol; synthesis - polyesterification; intermolecular exchange $[4,5]$.

The field of technical application of natural fats continues to expand, the volume of production of products based on vegetable oils significantly increases [6]. At the same time, attention should be focused on the fact that oil and synthetic lubricants and their components are toxic products. Some polycyclic aromatic hydrocarbons are carcinogenic [7].

Analyzing new, modern trends in the development of tribotechnics, one should note that one of the effective directions for implementing the concept of "green tribology" is the development of new lubricant compositions based on natural ecologically safe fats capable of biodegradation. A special weightage to such scientific research is given be the use of recycling technologies of secondary raw materials $[8,9]$.

The purpose of the paper is to study the effect of thickeners and fillers of different chemical nature on a new class of lubricants made on the basis of beef fat modified by waste polyethylene terephthalate

\section{Experimental part}

The aim of the work was to study the structure and tribotechnical characteristic of modified natural fat by grafting polyester oligomer (polyethylene terephthalate).

As the object of research beef fat was considered. According to the developed technology [10], synthesized intermediate com-pounds of acylglycerols of natural fats [11, 12], from which PET-acylglycerols of fats are synthesized. The latter were considered as the basic body of greases. To assess the structural characteristics of synthesized materials, rheometry and IR spectroscopy were used. The tribotechnical characteristics of the synthesized lubricants were determined on four-ball friction machine in accordance with the procedure [13].

\section{Results and discussion}

From the standpoint of the chemical structure, natural fats are compounds that are obtained as a result of the reaction between glycerol and aliphatic carboxylic acids with the formation of esters - acylglycerol (Fig. 1). 
By developed technologies for recycling waste PET bottles, we have obtained intermediate compounds - recyclables (PET oligesters) the combination of which with natural fats produces PET-acylglycerols (Fig. 2).

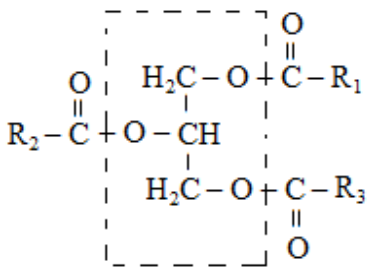

Fig. 1 - Structural formula of the composition of natural fats<smiles>[R]C(=O)OCC(COC([R])=O)OC(=O)CC</smiles>

Fig. 2 - Schematic form of synthesized PET-acylglycerol

On the output spectrum of beef fat (Fig. 3) characteristic transmission peaks are observed, an intense band with maxima at $2966 \mathrm{~cm}^{-1}, 2887 \mathrm{~cm}^{-1}, 2843 \mathrm{~cm}^{-1}$. These peaks can be attributed to stretching vibrations of (v) $\equiv \mathrm{C}$-H bond in the $\mathrm{CH}_{3}$ groups $\left(2962 \pm 10 \mathrm{~cm}^{-1}\right)$ and $=\mathrm{CH}_{2}\left(2926 \mathrm{~cm}^{-1}\right.$ and $\left.2853 \pm 10 \mathrm{~cm}^{-1}\right)$. The deformation vibrations $(\delta)=\mathrm{CH}_{2}$ correspond to peaks at $\left(1465 \pm 10 \mathrm{~cm}^{-1}\right)$ and $1380 \mathrm{~cm}^{-1}$ for $-\mathrm{CH}_{3}$ and $=\mathrm{CH}_{2}$. The intense band in the region of $1744 \pm 10 \mathrm{~cm}^{-1}$ is characteristic for valence vibrations of $=\mathrm{C}=\mathrm{O}$ bond. The stretching vibrations of the $\equiv \mathrm{C}-\mathrm{O}$ bond are manifested for the triacylglycerols of the three peaks of $1238 \mathrm{~cm}^{-1}$, $1242 \mathrm{~cm}^{-1}, 1170 \pm 10 \mathrm{~cm}^{-1}$.

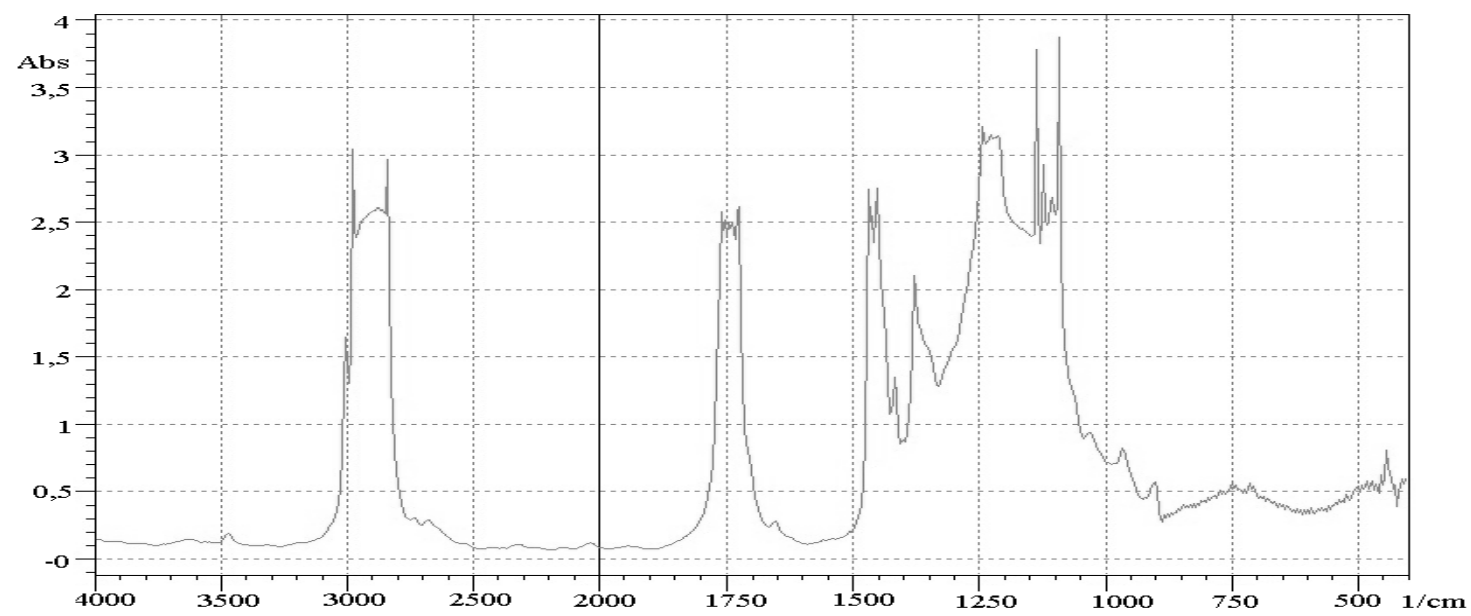

Fig. 3 - IR spectrogram of beef fat

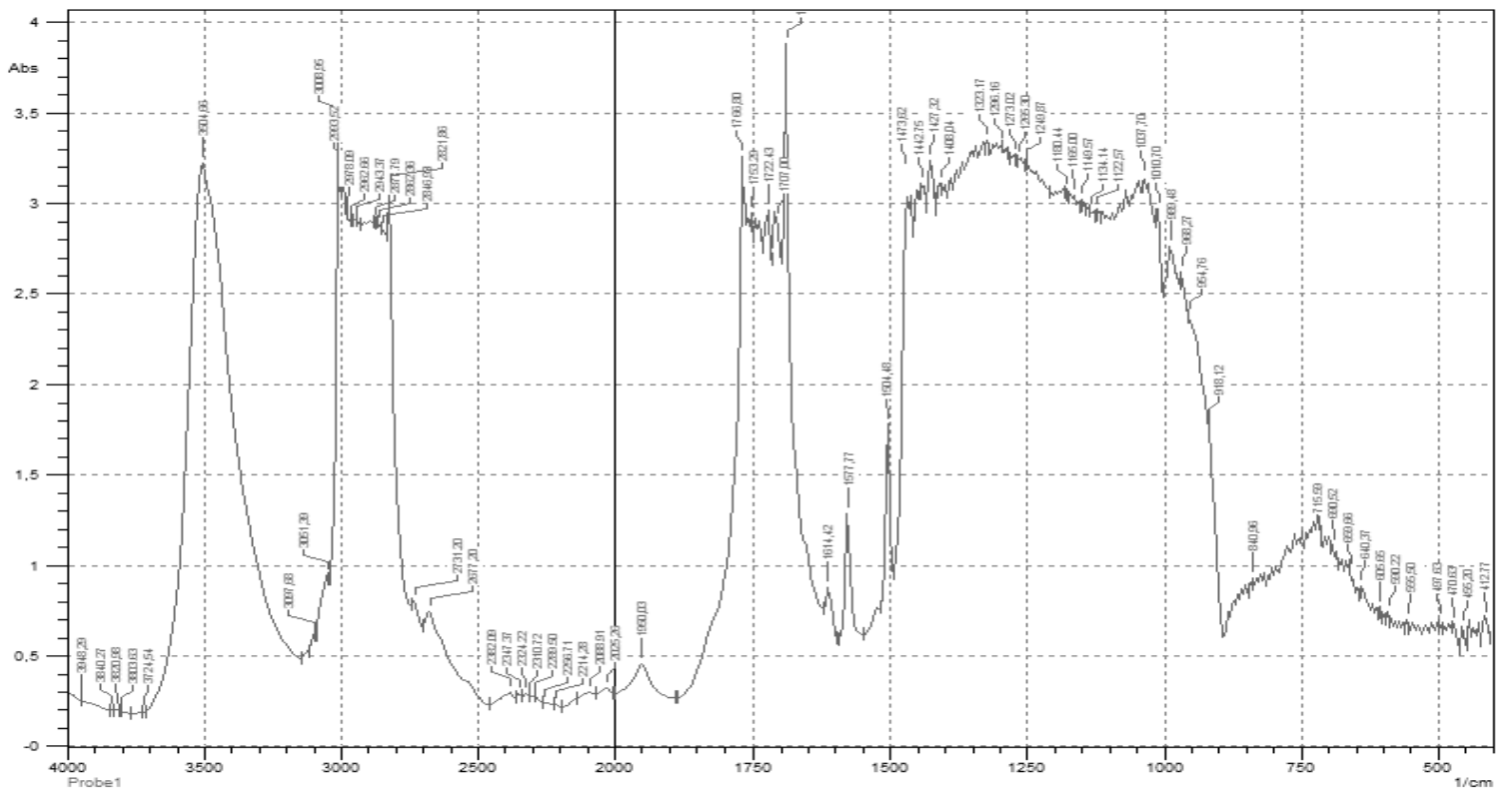

Fig. 4 - IR spectrogram of PET-acylglycerol based on beef fat 
On the IR spectrogram (Fig. 4) of the synthesized base bodies of lubricants base on beef fat and PET waste, it should be noted the appearance of bands in the region of $1577 \mathrm{~cm}^{-1}-$ stretching vibrations of the $\mathrm{C}-\mathrm{C}=$ benzene ring groups, deformation vibrations of the benzene ring in the plane at $1504 \mathrm{~cm}^{-1}$, which indicates the presence of fragments of the PET link in the composition of acylglycerol of beef fat.

One of the main components of the lubricant, which forms the structure and determines its main performance characteristics is a thickener. The main requirement for a thickener is the ability to form particularly fine, uniformly distributed particles in order to form a stable structure of the material. As a thickener we studied: paraffin P400, beeswax, aerosil 200, modified bentonite, sodium stearate and lithium stearate. As criteria for the effectiveness of thickening considered wear indicator and coefficient of friction.

In fig. 5 shows the nature of the change in the wear index, depending on the type and concentration of the thickening agent for lubricants based on PET-acylglycerol of beef fat.

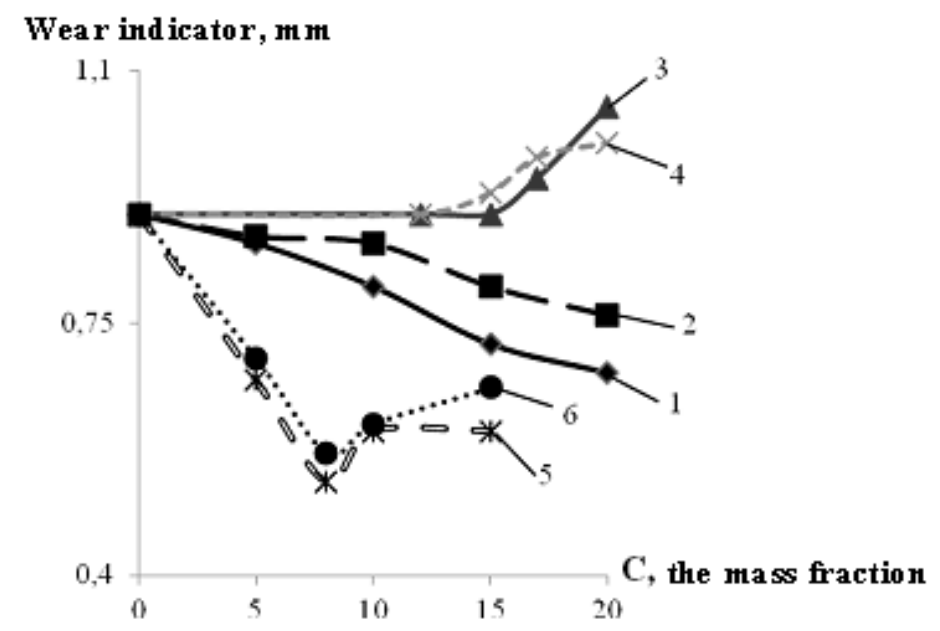

Fig. 5 - Change in wear indicator depending on the concentration of a thickener for a lubricant based on PET-acylglycerol of beef fat: 1 - paraffin P400; 2 - beeswax;

3 - modified bentonite; 4 - aerosil 200;

5 - sodium stearate;

6 - lithium stearate

Paraffin and beeswax somewhat reduce the wear indicator at a concentration of 10 m.f. to 20 m.f., at low content their presence in no way affects the process of wear of the material. The low content (from $12 \mathrm{~m} . f$. to 15 m.f.) of inorganic thickeners did not affect the change in wear indicator, however, with a further increase in concentration (from 17 m.f. to 20 m.f.) there is an increase.

The low concentration ( 5 m.f.) of metal stearates of lithium and sodium also does not affect the antiwear properties of the material, however, at a concentration of $8 \mathrm{~m}$.f. there is a significant effect and a sharp decrease in the wear indicator.

It should be noted that at high concentrations of stearates (10 m.f. and 15 m.f.) metals there is a certain increase in the wear index. This can be explained by the formation of a very strong structural framework, when the material flowing point is sufficiently high, that is, the base material (dispersed medium) does not stand out under the action of shear forces, and the thickener "glued" on the surface of the bodies of friction.

In fig. 6 - 11 depicts a change in the coefficient of friction of a lubricant based on PET-acylglycerol of beef fat, depending on the type and concentration of thickeners.

Analyzing the graphs, it can be concluded that the change in the coefficient of friction, depending on the type and concentration of the thickener, correlates with the data on the change in the wear indicator. That is, low concentrations of paraffin and wax practically do not affect the characteristics of the material; at higher concentrations there is a slight change in the indicators. These thickeners are fusible and suitable for use in preservative lubricants. Inorganic thickeners (aerosil 200, modified bentonite clay) at low concentrations slightly reduce the coefficient of friction, but with a further increase in their content, it increases. This indicates that lubricants with inorganic thickeners have low lubricating and protective properties. The lowest value of the coefficient of friction is observed for thickeners of metal stearates. Metal stearates are characterized by a polymorphism of a crystalline structure, that is, the crystals of the same soap can have different crystallographic forms at different temperatures and vary in density of packaging. 
One of the important functions of fillers in lubricants is to increase the stability of grease to shear stresses (displacement elastic modulus), to improve their anti-wear and anti-wearing functions (for antifriction fillers), which receive special significance at high loads, speeds and a wide temperature range of operation machines and mechanisms. As fillers we studied aerosil 200, modified with quaternary ammonium salts bentonite clay (particle size is $20 \mathrm{~nm}$ ), antifriction fillers - talc, graphite and molybdenum disulfide.

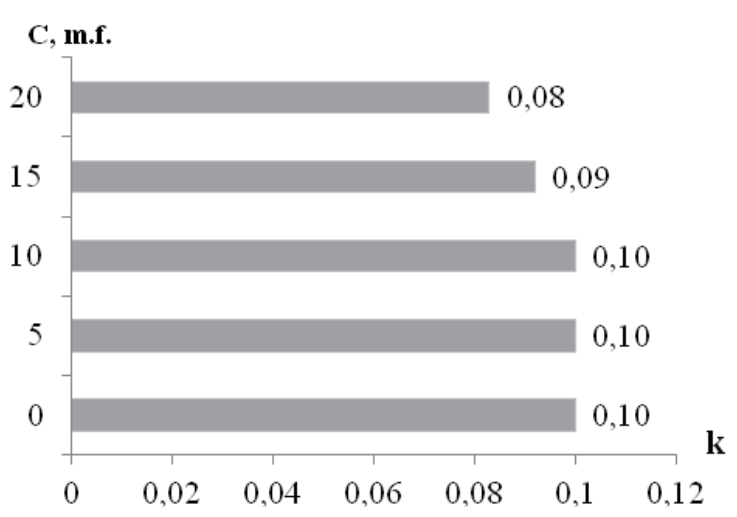

Fig. 6 - Friction coefficient for the developed lubricant with different concentrations of P400 paraffin

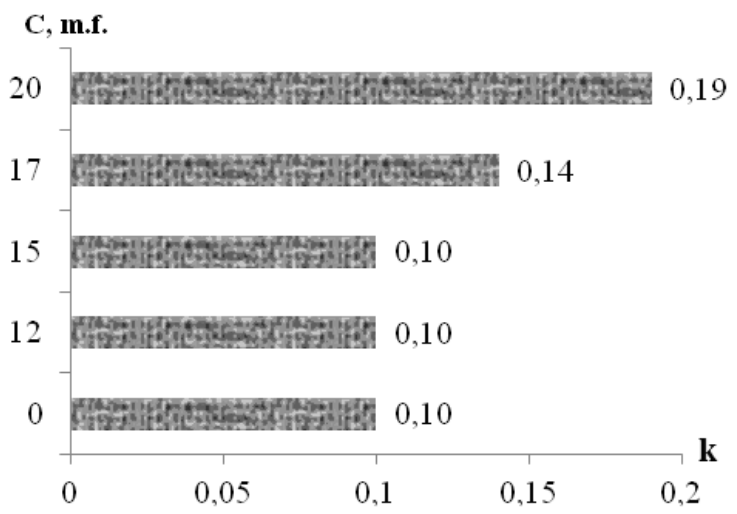

Fig. 8 - Friction coefficient for the developed lubricant with different concentrations of aerosil 200

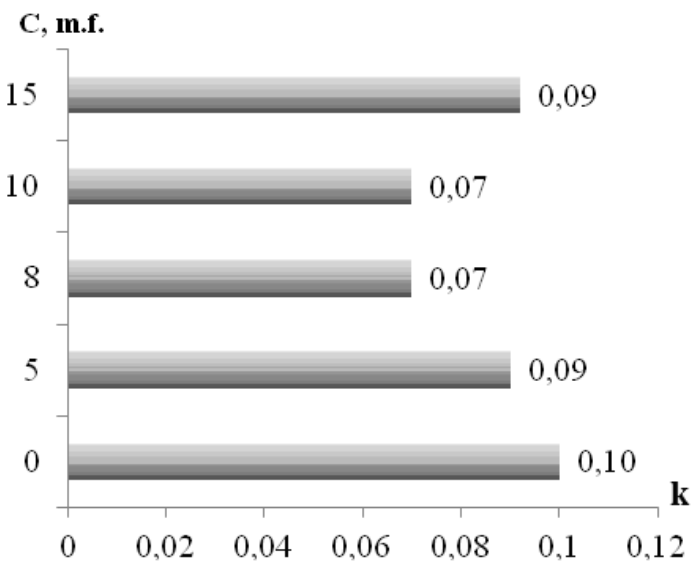

Fig. 10 - Friction coefficient for the developed lubricant with different concentrations of sodium stearate

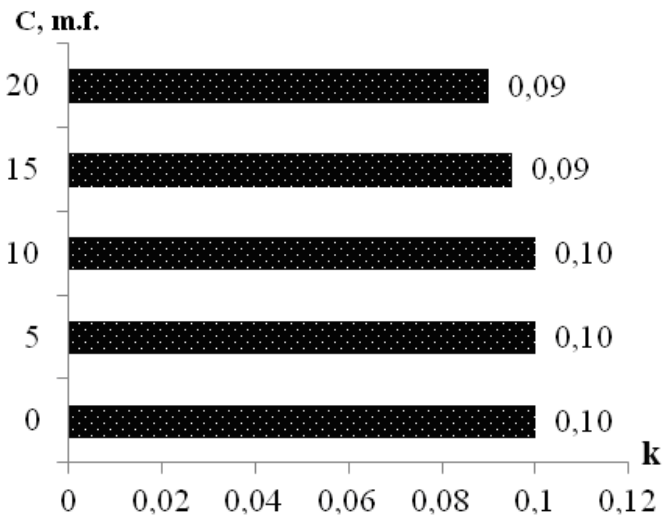

Fig. 7 - Friction coefficient for the developed lubricant with different concentrations of beeswax

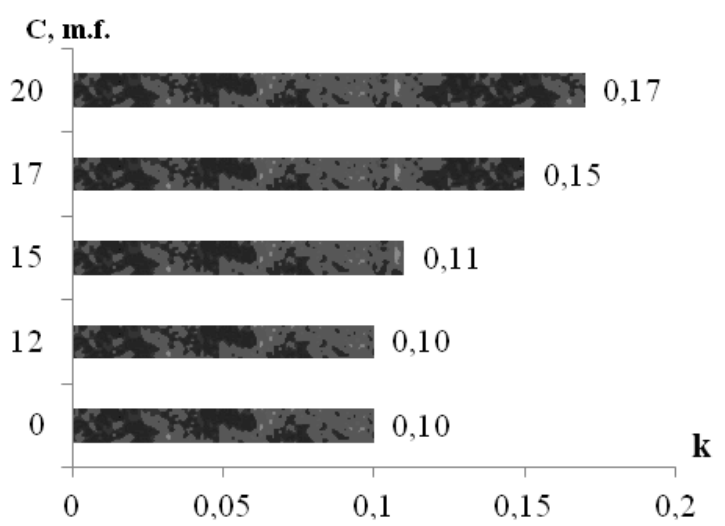

Fig. 9 - Friction coefficient for the developed lubricant with different concentrations of concentrations of bentonite

C, m.f.

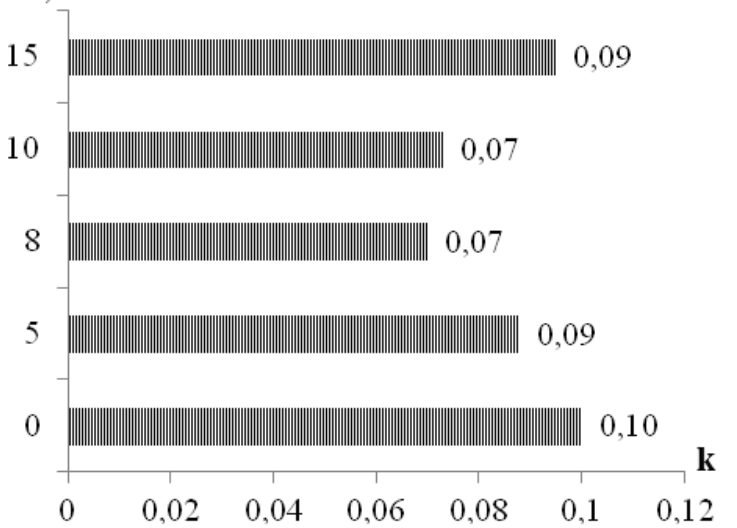

Fig. 11 - Friction coefficient for the developed lubricant with different concentrations of lithium stearate

In the study of the lubricity of materials, [14] it was found that the effect of fillers on anti-wear properties was largely determined by the nature of the thickener. When using thickeners that form a rigid structure, the fillers are held in the frame of the lubricating material and do not enter the friction zone. Therefore, the above- 
Investigation of the influence of thickeners and fillers on properties of lubricants obtained by recycling technologies

mentioned fillers were added to thickened materials with sodium stearate, the introduction of which does not lead to a significant increase in the yield line, retains the thixotropy of the system, which in turn allows the antifriction fillers to enter the friction zone.

In tab. 1 shows the value of the static shear stress $\tau_{0}$ for the thickened material with fillers.

Table 1

\section{Static shear stress for materials with fillers}

\begin{tabular}{|l|c|}
\hline \multicolumn{1}{|c|}{ Material } & Value $\tau_{0}, \mathrm{~Pa}$ \\
\hline The lubricant is developed + sodium stearate & 59,5 \\
\hline The lubricant is developed + sodium stearate $+12 \%$ talc & 262 \\
\hline The lubricant is developed + sodium stearate $+17 \%$ talc & 386 \\
\hline The lubricant is developed + sodium stearate $+12 \%$ aerosil & 495 \\
\hline The lubricant is developed + sodium stearate $+17 \%$ aerosil & 1487,5 \\
\hline The lubricant is developed+sodium stearate $+12 \%$ bentonite & 81,2 \\
\hline The lubricant is developed+sodium stearate $+17 \%$ bentonite & 93,2 \\
\hline The lubricant is developed+sodium stearate $+3 \%$ graphite & 184 \\
\hline The lubricant is developed+sodium stearate $+8 \%$ graphite & 357 \\
\hline The lubricant is developed+sodium stearate $+3 \%$ molybdenum disulfide & 247 \\
\hline The lubricant is developed+sodium stearate $+8 \%$ molybdenum disulfide & 379 \\
\hline
\end{tabular}

Based on the analysis of the results presented in tab. 1, it can be concluded that when adding different types of fillers, there is an increase in the value $\tau_{0}$ - static bias voltage. This is more pronounced when an aerosil is introduced.

At the same time, the addition of bentonite does not lead to a sharp increase in the value of $\tau_{0}$, that is, by modifying with the quaternary ammonium salts of the surface of particles of bentonite clay, it is possible to adjust the value of $\tau_{0}$.

Data tab. 2 allows you to analyze the lubricity of filled lubricants developed on the basis of beef fat and waste polyethyleneterephthalate.

Table 2

Anti-wear properties of filled lubricants on the basis of PET-acylglycerol of beef fat

\begin{tabular}{|c|c|c|c|c|c|c|c|c|c|c|c|}
\hline \multirow[b]{2}{*}{ 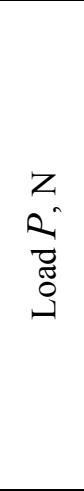 } & \multicolumn{11}{|c|}{ Diameter of stains of wear, $\mathrm{mm}$} \\
\hline & 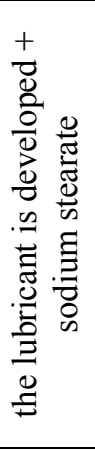 & 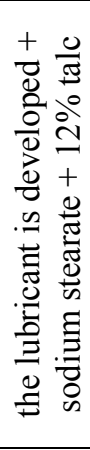 & 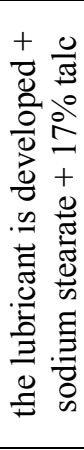 & 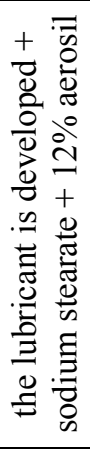 & 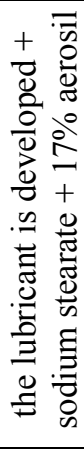 & 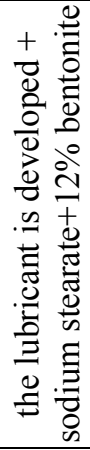 & 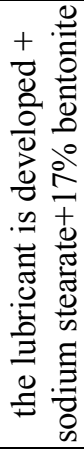 & 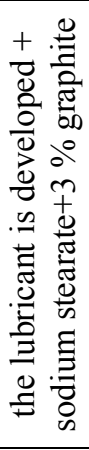 & 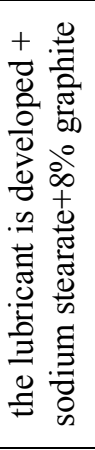 & 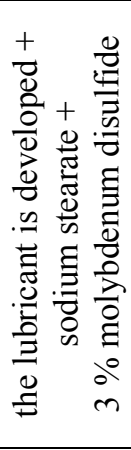 & 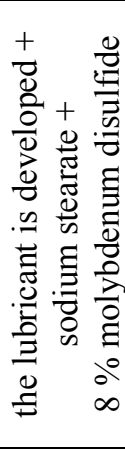 \\
\hline 617 & 0,34 & 0,34 & 0,35 & 0,34 & 0,36 & 0,34 & 0,34 & 0,33 & 0,33 & 0,32 & 0,31 \\
\hline 823 & 0,7 & 0,58 & 0,62 & 0,65 & 0,65 & 0,51 & 0,60 & 0,46 & 0,42 & 0,41 & 0,40 \\
\hline 1039 & 1,00 & 0,83 & 0,95 & 0,84 & 0,96 & 0,70 & 0,81 & 0,76 & 0,70 & 0,60 & 0,50 \\
\hline 1166 & 1,70 & 0,96 & 1,25 & 1,00 & 1,30 & 0,9 & 1,00 & 0,80 & 0,76 & 0,70 & 0,62 \\
\hline 1381 & 2,45 & 1,00 & 1,34 & 1,40 & 2,00 & 1,20 & 1,30 & 0,84 & 0,80 & 0,70 & 0,68 \\
\hline
\end{tabular}

The table shows the diameter of the wear spots depending on the type and concentration of the filler with consistent increase of loads.

It should be noted that in the range of low loads the role of fillers does not significantly manifest, therefore, to demonstrate the influence on the lubricating properties of the materials developed, the interval of transition from medium to high loads was chosen. 
From the data of the table it is seen that the introduction of selected fillers leads to a decrease in the value of diameter of the stain wear. However, in the entire load range, the MoS2 and graphite lubricants are most effective, especially at high loads, for example, when loaded at $1381 \mathrm{~N}$, the diameter of the wear depreciation is reduced to $70 \%$ at $3 \%$ filling. Increasing the concentration to $8 \%$ slightly improves the lubricity, so it is not expedient.

In fig. 12 depicts traces of wear on steel balls taken with scanning electron microscopy.

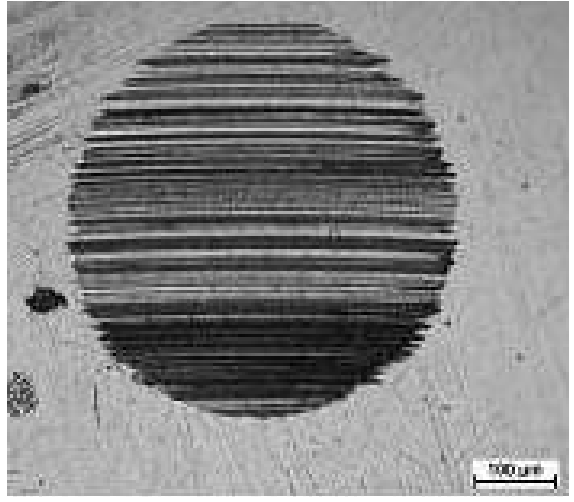

a

beef fat

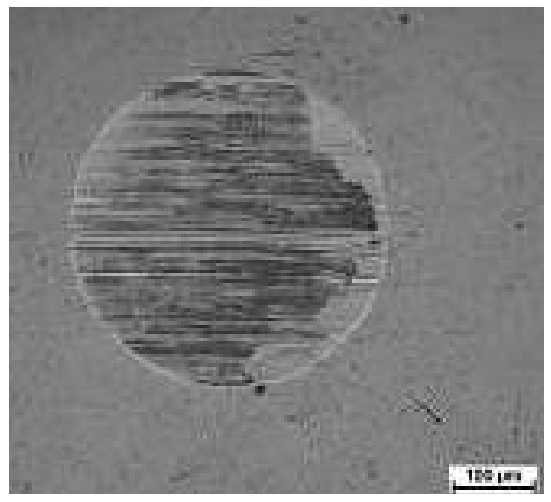

b

Fig. 12 - Wear traces obtained by means of scanning electron microscopy on experimental balls with a load of $150 \mathrm{~N}$

In case of using beef fat as a lubricant, the limiting friction regime is observed with an equalization of the friction surface due to smoothing of the microroughnesses.

The type of wear spot when rubbing with a synthesized body (Fig. 12b) indicates the signs of plastic deformation of a thin layer of metal in the friction zone, which manifests itself in the formation of a mass of metal in front of the ball when it moves. Plastic deformation of the metal is evidence of the formation of the intermediate layer in the contact zone, due to the phenomena of adsorption of the lubricating oil on the active centers of the metal surface [15].

\section{Conclusions}

It is established that the addition of antifriction fillers (talc, molybdenum disulfide, graphite) results in an increase in the values of the shear stress by 6 times compared to the composition without a filler, the diameter of the stain wear decreases by $70 \%$. Among the investigated thickeners, the most effective was sodium stearate, the wear indicator decreased by $41 \%$, the friction coefficient - by $30 \%$.

\section{References}

1. Czichos Horst, Habig Karl-Heinz Tribologie Handbuch, 2010, 757 p.

2. Reznikov V.D., Shestakovskaya T.V., Dovgopolyiy E.E. Chepurova M.B. Zarubezhnyie masla, smazki, prisadki, tehnicheskie zhidkosti: Mezhdunarodnyiy katalog, 2005, 383 s. (in Russian).

3. Dekl. patent 60710A Ukrayina, MPK7 S O8 J11/00. Sposib pererobky vidkhodiv polietylentereftalatu / I. A. Mandzyuk, V. M. Holonzhko, T. V. Ivanishena (Ukrayina); zayavnyk i patentovlasnyk Khmel'nyts'kyy derzhavnyy universytet. - № 2003021112 ; zayavl. 07.02.03 ; opubl. 15.10.03, Byul. № 10. - 3 s. (in Ukrainian).

4. Mandzyuk I. A., Ivanishhena T. V. Investigation of chemical recycling - glycolysis of polyethylene terephthalate, Bulletin of Technological University of Podillya, 2002, No 5, pp 186-189.

5. Mandzyuk I. A. Questions about handling industrial and household waste, Eco-technology and resource-saving, 2003, No 3, pp. 41-43.

6. Ostrikov V.V., Nagornov S.A., Kleymenov O.A., Prohorenkov V.D., Kurochkin I.M., Hrennikov A.O., Dorovskih D.V. Toplivo, smazochnyie materialyi i tehnicheskie zhidkosti, 2008, 128 s. (in Russian).

7. Byrne C. J., Calder J. A. Effect of the Water-soluable Fractions of Crude, Refined and Waste Oils on the Embryonic and Larval Stages of the Quahog Clam, Marine Biology, 1977, No 40, pp. 225-231.

8. Mandzyuk I. A., Prysiazhnaya E.A. Razrabotka smazochnyih materialov v ramkah kontseptsii "Zelenoy tribologii”, FundamentalnI ta prikladnI dosIIdzhennya u suchasnIy nautsI : zb. nauk. pr. IV nauk. konferentsIYi. - HarkIv : TehnologIchniy Tsentr, 2016. - 100 s. (in Ukrainian). 
Investigation of the influence of thickeners and fillers on properties of lubricants obtained by recycling technologies

9. Padgurskas J., Rukuiža R., Mandziuk I., Kupcinskas A., Prisyazhna K., Grigoriev A., Kavaliova I., Revo R. Tribological properties of beef tallow as lubricating grease, Industrial Lubrication and Tribology, 2017, Vol. 69, No 5, pp 645-654.

10. Patent na vynakhid 114226 S2 Ukrayina, MPK (2017.01) C10M 177/00 C10M 105/06 (2006.01) C10M 117/00. Sposib syntezu biodehraduyuchoyi bazovoyi osnovy mastyl'nykh materialiv / I. A. Mandzyuk, K. O. Prysiazhna (Ukrayina); zayavnyk i patentovlasnyk Khmel'nyts'kyy natsional'nyy universytet. - № a 2015 07870 ; zayavl. 07.08.2015 ; opubl. 10.05.2017, Byul №9. - 7 s. (in Ukrainian)

11. Dekl. patent na korysnu model' №110856 Ukrayina, MPK7 S10M 107/04, C10M 101/00, C11C 3/06, C10N 40/02. Sklad konsystentnoho mastyla / I. A. Mandzyuk, K. O. Prysyazhna ; zayavnyk i patentovlasnyk Khmel'nyts'kyy natsional'nyy universytet. - № u201603572 ; zayavl. 04.04.2016 ; opubl. 25.10.2016, Byul. № 20. - 3 s. (in Ukrainian)

12. Dekl. patent na korysnu model' № 110857 Ukrayina, MPK7. Konsystentne mastylo / I. A. Mandzyuk, K. O. Prysyazhna ; zayavnyk i patentovlasnyk Khmel'nyts'kyy natsional'nyy universytet. - № u201603574 ; zayavl. 04.04.2016 ; opubl. 25.10.2016, Byul. № 20. - 3 s. (in Ukrainian)

13. DIN 51350 Testing of lubricants - Testing in the four-ball tester - Parts 1-5. - Publ. 2015-03-01. Berlin : German National Standard, 2015. - 33 p. (in German)

14. Fuks I. H. Dobavky k plastycheskym smazkam, M.: Khymyya, 1982, 248 s. (in Russian).

15. Mandzyuk I. A., Prysiazhna K.O. Novyy klas osnov mastyl'nykh materialiv za vymohamy "zelenoyi trybolohiyi”, Problemy trybolohiyi. - 2017. - № 1. - S. 35-40. (in Ukrainian).

Мандзюк І.А., Присяжна К.О. Дослідження впливу загусників та наповнювачів на властивості мастильних матеріалів, отриманих за технологіями реціклінгу.

Розглянуто можливість отримання нового класу основ мастильних матеріалів шляхом модифікації молекули природного жиру фрагментом ланки синтетичного полімеру - поліетилентерефталату. Досліджено вплив загусників різної хімічної природи: парафін Р400, бджолиний віск, аеросил 200, модифікований бентоніт, натрію стеарат і стеарат літію на антифрикційні характеристики ПЕТ-ацилгліцерину на основі яловичого жиру. Розглянуто вплив наповнювачів, а саме: аеросилу 200, модифікованої четвертинними амонієвими солями бентонітової глини (розмір часток 20 нм), тальк, графіт і дисульфід молібдену на величину статичного зсувного напруги та протизносні властивості.

Ключові слова: природний жир, ПЕТ-ацилгліцерол, ІЧ-спектрограма, мастильний матеріал, триботехнічні властивості, коефіцієнт тертя.

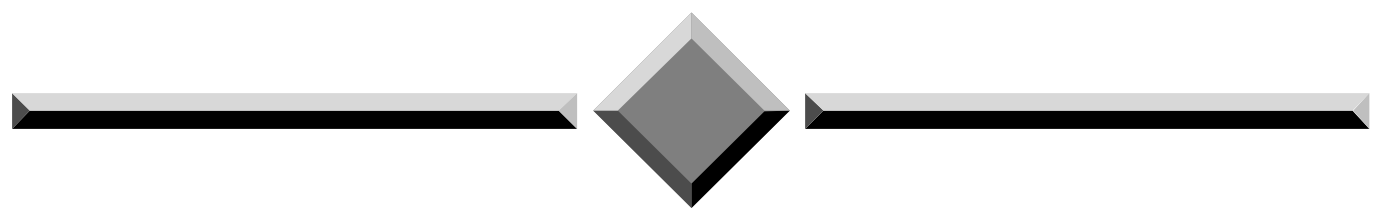

\section{"Problems of Tribology" E-mail: tribosenator@gmail.com}

